\title{
Pengaruh Kemampuan Berpikir Kreatif dan Berinteraksi Sosial terhadap Keterampilan Menulis Cerita Pendek Bahasa Indonesia
}

\author{
Siti Jamilah \\ Universitas Indraprasta PGRI \\ Jalan Nangka No. 58 C/TB. Simatupang, Tanjung Barat, Jakarta Selatan 12530
}

\begin{abstract}
The purpose of this study was to determine the effect of creative thinking ability and social interaction on Indonesian short story writing skills. This study uses a survey method with regression and correlational analysis techniques. The subjects of the study were students of class XI Private Madrasah Aliyah in South Jakarta. The research was conducted at Madrasah Aliyah Sa'adatuddarain and Madrasah Aliyah Islamiyah PUI. Research sampling technique using simple random sampling technique (Simple Random Sampling). Short story writing skills data and creative thinking ability data were collected with product tests, while data on social interaction abilities were collected using a questionnaire or questionnaire. Based on the results of the hypothesis and data analysis, the following conclusions are drawn: 1). There is a significant influence of the ability to think creatively and interact socially together on the skills of writing short stories in Indonesian private MA students in South Jakarta. This is evidenced by the acquisition of Sig. 0,000<0.05 and $F h=11,023.2)$. There is a significant influence of the ability to think creatively on Indonesian short story writing skills for MA Private students in South Jakarta. This is evidenced by the acquisition of Sig. $0.006<0.05$ and th $=2.831 .3$ ). There is a significant influence of social interaction on the skills of writing short stories Indonesian private MA students in South Jakarta. This is evidenced by the acquisition of Sig. $0.038<0.05$ and th $=2.127$.
\end{abstract}

Keywords: creative thinking ability, social interaction ability.

\begin{abstract}
Abstrak
Tujuan dari penelitian ini adalah untuk mengetahui pengaruh kemampuan berpikir kreatif dan berinteraksi sosial terhadap keterampilan menulis cerita pendek bahasa Indonesia. Penelitian ini menggunakan metode survei dengan teknik analisis regresi dan korelasional. Subjek penelitian adalah siswa kelas XI Madrasah Aliyah Swasta di Jakarta Selatan. Penelitian dilaksanakan di Madrasah Aliyah Sa'adatuddarain dan Madrasah Aliyah Islamiyah PUI. Teknik pengambilan Sampel penelitian dengan menggunakan teknik sampling acak sederhana (Simple Random Sampling). Data keterampilan menulis cerita pendek dan data kemampuan berpikir kreatif dikumpulkan dengan tes produk, sedangkan data kemampuan berinteraksi sosial dikumpulkan dengan menggunakan kuesioner atau angket. Berdasarkan hasil hipotesis dan analisis data, disimpulkan beberapa hal berikut: 1). Terdapat pengaruh yang signifikan kemampuan berpikir kreatif dan berinteraksi sosial secara bersama-sama terhadap keterampilan menulis cerita pendek bahasa Indonesia siswa MA Swasta di Jakarta Selatan. Hal ini dibuktikan dengan perolehan nilai Sig. $0,000<0,05$ dan $\mathrm{Fh}=11,023$. 2). Terdapat pengaruh yang signifikan kemampuan berpikir kreatif terhadap keterampilan menulis cerita pendek bahasa Indonesia siswa MA Swasta di Jakarta Selatan. Hal ini dibuktikan dengan perolehan nilai Sig. $0,006<0,05$ dan th $=2,831$. 3). Terdapat pengaruh yang signifikan berinteraksi sosial terhadap keterampilan menulis cerita pendek bahasa Indonesia siswa MA Swasta di Jakarta Selatan. Hal ini dibuktikan dengan perolehan nilai Sig. 0,038 $<0,05$ dan th $=2,127$.
\end{abstract}

Kata Kunci: kemampuan berpikir kreatif, kemampuan berinteraksi sosial

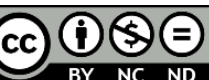

Creative Commons Attribution-NonCommercial-NoDerivatives 4.0 International License 


\section{PENDAHULUAN}

Dalam mempelajari bahasa, terdapat lima aspek keterampilan yang harus dikuasai, yaitu menyimak, berbicara, membaca, menulis dan memirsa. Sebagian beranggapan bahwa menulis merupakan keterampilan yang paling sulit dikuasai dibanding dengan aspek keterampilan bahasa yang lainnya. Sebagaimana yang telah diutarakan oleh Ridwan (2011:83) yang mengatakan bahwa kemampuan menulis merupakan kemampuan yang kompleks, sebab menulis mengharuskan seseorang mengerahkan segenap kemampuannya yang berupa penguasaan aspekaspek kebahasaan, isi tulisan, teknik penulisan, dan juga tentang hal yang akan ditulis serta bagaimana menyampaikannya dalam bahasa tulis. Menulis dikatakan keterampilan yang paling sulit dibandingkan keterampilan yang lainnya, karena untuk mampu menulis, seseorang perlu menguasai unsur kebahasaan dan unsur di luar bahasa yang akan menjadi isi tulisan.

Kreativitas dan pengetahuan merupakan salah satu unsur di luar bahasa yang ikut berpengaruh terhadap kemampuan menulis. Menurut Dalman (2014:4-6) menyatakan bahwa menulis merupakan proses menyampaikan pikiran, anganangan, perasaan, atau informasi secara tertulis berupa hasil kreativitas penulisnya dengan menggunakan cara berpikir yang kreatif, tidak monoton, dan tidak terpusat pada satu pemecahan masalah saja.

Pengertian ini menerangkan bahwa di dalam menulis terdapat beberapa aspek, yaitu tujuan atau maksud yang hendak dicapai, pikiran atau sesuatu yang hendak disampaikan, dan sistem pemindahan pikiran ke dalam tulisan. Sistem pemindahan pikiran itu berupa bahasa, lalu dipindahkan dengan proses berpikir yang kreatif. Dengan demikian, menulis memang merupakan sesuatu yang sulit dikuasai karena menulis memerlukan kreativitas dan pengetahuan atau apresiasi yang lebih.

Salah satu bentuk tulisan yang berisi kreativitas adalah cerita pendek atau cerpen. Cerita pendek adalah bagian dari menulis kreatif. Menulis terbagi atas dua jenis yaitu menulis akademis dan menulis kreatif. Menulis akademis berkaitan dengan suatu hal yang konkret, nyata atau sesuai fakta, sedangkan menulis kreatif berkaitan dengan dunia tidak nyata atau rekaan dan berisi imajinasi. Menulis akademis bersifat non-fiksi dan disusun berdasarkan kaidah penulisan yang baku, biasanya berbentuk karya ilmiah, seperti makalah, skripsi, atau tesis. Sedangkan menulis kreatif bersifat fiksi seperti naskah drama, novel dan cerpen.

Cerita pendek merupakan media untuk menceritakan sebuah pengalaman, baik pengalaman diri sendiri maupun pengalaman orang lain yang ditambahi imajinasi atau direka-reka. Pada pembelajaran di sekolah terkait materi tentang menulis cerita pendek, siswa dituntut mampu mengungkapkan pikiran, perasaan, informasi, dan pengalaman secara tertulis dalam bentuk karang cerita pendek. Namun dalam kenyataannya, banyak siswa yang tidak mampu mengungkapkan pikiran, perasaan, informasi dan pengalaman secara tertulis dalam bentuk karangan cerita pendek.

Keterampilan menulis cerita pendek bukanlah sesuatu yang dapat diajarkan melalui uraian dan penjelasan teori saja. Siswa tidak dapat memperoleh keterampilan tersebut dengan hanya duduk, mendengarkan, dan mencatat penjelasan guru. Keterampilan menulis cerita pendek dapat ditingkatkan melalui 
kegiatan menulis cerita pendek secara terus menerus sehingga akan mempengaruhi hasil dan prestasi siswa dalam menulis cerita pendek. Menulis cerpen memang tidak mudah. Pengalaman peneliti di lapangan diperoleh data bahwa siswa mengalami kesulitan dalam mendapatkan ide, tema, atau topik yang akan ditulisnya.

Ide, tema atau topik akan mudah didapatkan apabila siswa memiliki pengalaman, wawasan, dan pengetahuan yang luas. Selain itu, ide cerita atau tema pada cerpen dapat diambil dari pengalaman-pengalaman hidup, baik pengalaman pribadi maupun pengalaman orang-orang di sekitar yang didapat dari interaksi sosial.

Manusia sebagai makhluk sosial berarti manusia perlu berinteraksi kepada sesamanya untuk memenuhi kebutuhan hidupnya. Dalam berinteraksi sosial, manusia memerlukan bahasa sebagai alat untuk berkomunikasi. Seperti yang diutarakan oleh Chaer dan Agustina (2004:14-15) bahwa bahasa merupakan alat untuk berinteraksi sosial atau alat untuk berkomunikasi, dalam arti, alat untuk menyampaikan pikiran, gagasan, konsep, atau juga perasaan. Untuk itu bahasa dinilai sebagai alat yang sangat penting bagi manusia, sehingga manusia perlu mempelajari bahasa.

Kesulitan siswa dalam menulis cerpen tidak hanya pada pemerolehan ide dan penentuan tema saja. Banyak siswa yang mengalami kesulitan ketika harus menuangkan ide atau gagasannya ke dalam tulisan. Saat tema sudah didapat dan sudah ditentukan, banyak siswa yang selalu berhenti pada kalimat atau paragraph pertama. Proses penulisan menuntut siswa untuk lancar dalam berpikir sehingga siswa dapat mengolah kata-kata untuk memaparkan ide atau gagasannya. Siswa harus memiliki kemampuan berpikir kreatif dalam membuat cerpen.

Pengalaman peneliti saat melakukan penelitian, menemukan fakta bahwa siswa yang memiliki kemampuan berpikir kreatif dan sering berinteraksi sosial memperoleh nilai tinggi pada hasil tulisan cerpennya. Hal ini membuat peneliti semakin tertarik membuat penelitian terkait pengaruh kemampuan berpikir kreatif dan berinteraksi sosial terhadap keterampilan menulis cerita pendek bahasa Indonesia. Peneliti akan mencari tahu apakah memang terdapat pengaruh kemampuan berpikir kreatif dan berinteraksi sosial terhadap keterampilan menulis cerita pendek bahasa Indonesia.

\section{METODE}

"Penelitian ini dilakukan di Madrasah Aliyah Swasta di Jakarta Selatan, yaitu Madrasah Aliyah Islamiyah PUI dan Madrasah Aliyah Sa'adatuddarain dengan objek penelitian adalah siswa kelas XI. Penelitian ini adalah penelitian yang menguji dua variabel bebas terhadap satu variabel terikat. Dua variabel bebas yang dimaksud adalah Kemampuan berpikir kreatif (X1) dan kemampuan berinteraksi sosial (X2), sedangkan keterampilan menulis cerpen adalah variabel terikat (Y).

Penelitian ini menggunakan metode survei dengan teknik analisis regresi dan korelasional. Pendekatan penelitian ini bersifat kuantitatif karena data yang dikumpulkan merupakan data kuantitatif berupa skor variabel yang diteliti 
Diskursus: Jurnal Pendidikan Bahasa Indonesia Vol. 2, No. 3, Desember 2019, pp. 259-266 p-ISSN: 2615-4935 e-ISSN: 2615-4943

(Arikunto, 2006). Data dikumpulkan menggunakan instrumen yang berupa kuesioner atau angket dan tes produk.

\section{HASIL DAN PEMBAHASAN}

Hasil

Tabel 1. Hasil Perhitungan Pengujian Koefisien Korelasi Ganda Variabel $\mathrm{X}_{1}$ dan $\mathrm{X}_{2}$ terhadap $\mathrm{Y}$

\begin{tabular}{|l|r|c|r|c|}
\hline \multicolumn{5}{|c|}{ Model Summary } \\
\hline Model & $\mathrm{R}$ & R Square & Adjusted R Square & $\begin{array}{c}\text { Std. Error of the } \\
\text { Estimate }\end{array}$ \\
\hline 1 &, $528^{\mathrm{a}}$ & \multicolumn{2}{|c|}{, 279} &, 254 \\
\hline a. Predictors: (Constant), Berinteraksi Sosial, Kemampuan Berpikir Kreatif \\
\hline
\end{tabular}

Tabel 2. Hasil Perhitungan Pengujian Signifikansi Koefisien Regresi Variabel $X_{1}$ dan $X_{2}$ terhadap $Y$

\begin{tabular}{|l|l|r|r|r|c|c|}
\hline \multicolumn{7}{|c|}{ ANOVA $^{\text {a }}$} \\
\hline Model & Sum of Squares & Df & Mean Square & F & Sig. \\
\hline \multirow{3}{*}{1} & Regression & 898,401 & 2 & 449,200 & 11,023 &, $000^{\text {b }}$ \\
\cline { 2 - 7 } & Residual & 2322,849 & 57 & 40,752 & & \\
\cline { 2 - 7 } & Total & 3221,250 & 59 & & & \\
\hline
\end{tabular}

Tabel 3. Hasil Perhitungan Persamaan Regresi Ganda Variabel $\mathrm{X}_{1}$ dan $\mathrm{X}_{2}$ terhadap Y

\begin{tabular}{|c|c|c|c|c|c|c|}
\hline \multicolumn{7}{|c|}{ Coefficients $^{\mathbf{a}}$} \\
\hline \multirow{2}{*}{\multicolumn{2}{|c|}{ Model }} & \multicolumn{2}{|c|}{$\begin{array}{l}\text { Unstandardized } \\
\text { Coefficients }\end{array}$} & \multirow{3}{*}{$\begin{array}{c}\text { Standardized } \\
\text { Coefficients }\end{array}$} & \multirow[t]{2}{*}{$\mathrm{t}$} & \multirow[t]{2}{*}{ Sig. } \\
\hline & & $\mathrm{B}$ & Std. Error & & & \\
\hline \multirow{3}{*}{1} & (Constant) & 30,171 & 10,342 & & 2,917 &, 005 \\
\hline & $\begin{array}{l}\text { Kemampuan } \\
\text { Berpikir } \\
\text { Kreatif }\end{array}$ & ,335 &, 119 &, 354 & 2,831 & ,006 \\
\hline & $\begin{array}{l}\text { Berinteraksi } \\
\text { Sosial }\end{array}$ &, 225 & ,106 & ,266 & 2,127 & ,038 \\
\hline
\end{tabular}


Data Keterampilan Menulis Cerita Pendek Bahasa Indonesia (Y)

Bila dilihat dari hasil perhitungan, maka bisa dikatakan bahwa Keterampilan Menulis Cerita Pendek Bahasa Indonesia di Madrasah Aliyah Swasta di Jakarta Selatan cukup baik. Hal ini diindikasikan dengan perolehan nilai rata-rata sebesar 77.75

\section{Deskripsi Data Penelitian Kemampuan Berpikir Kreatif}

Dari hasil perhitungan, maka bisa dikatakan bahwa kemampuan berpikir kreatif siswa MA Swasta di Jakarta Selatan tergolong tinggi. Hal ini diindikasikan dengan perolehan skor rerata sebesar 76,75.

\section{Deskripsi Data Penelitian Berinteraksi Sosial}

Dari hasil perhitungan, maka bisa dikatakan bahwa kemampuan berinteraksi sosial siswa MA Swasta di Jakarta Selatan cukup tinggi. Hal ini diindikasikan dengan perolehan nilai rerata skor berinteraksi sosial 96,98.

\section{Uji Persyaratan Analisis Regresi}

Dari data penelitian menunjukkan bahwa uji hipotesis yang menyatakan distribusi data pada analisis regresi ini mengikuti distribusi normal. Hal ini ditunjukkan dengan semua nilai Asymp. Sig >0,05. Hal ini berarti semua data berdistribusi normal.

\section{Uji Multikolinearitas}

Hasil uji multikolininearitas diketahui bahwa hasil Tolerance 0,808 $>0,1$ atau Varian Inflation Factor (VIF) 1,238 < 10. Sehingga dapat dinyatakan bahwa tidak ada multikolinearitas antara kemampuan berpikir kreatif dengan berinteraksi sosial pada analisis regresi ganda ini.

\section{Uji Normalitas Galat}

Data menunjukkan bahwa uji hipotesis yang menyatakan distribusi residual pada analisis regresi ini mengikuti distribusi normal. Hal ini ditunjukkan dengan nilai $\mathrm{Z}=0,607$ dan Sig. $=0,854>0,05$. Hal ini berarti asumsi atau persyaratan analisis regresi terpenuhi.

\section{Hasil Pengujian Linearitas Regresi Variabel Y atas $X_{I}$}

Berdasarkan hasil perhitungan diperoleh hasil perhitungan Deviation from Linearity dengan Fo $=0,590$ dan Sig. $=0,708>0,05$. Hal ini memiliki pengertian bahwa variabel kemampuan berpikir kreatif dengan keterampilan menulis cerita pendek bahasa Indonesia siswa MA swasta di Jakarta Selatan mempunyai hubungan yang linear.

\section{Hasil Pengujian Linearitas Regresi Variabel Y atas $\mathrm{X}_{2}$}

Berdasarkan hasil perhitungan diperoleh hasil Deviation from Linearity dengan Fo $=0,903$ dan Sig. $=0,562>0,05$. Hal ini memiliki pengertian bahwa variabel berinteraksi sosial dengan keterampilan menulis cerita pendek bahasa Indonesia siswa MA swasta di Jakarta Selatan mempunyai hubungan yang linear. 


\section{Pengujian Hipotesis Penelitian}

Pengujian hipotesis ini dilakukan dengan cara menguji dua variabel bebas terhadap satu variabel terikat. Dua variabel bebas yang dimaksud adalah Kemampuan berpikir kreatif (X1) dan kemampuan berinteraksi sosial (X2), sedangkan keterampilan menulis cerpen adalah variabel terikat (Y).

\section{Pembahasan}

Pengaruh kemampuan berpikir kreatif (X1) dan berinteraksi sosial (X2) secara bersama-sama terhadap keterampilan menulis cerita pendek bahasa Indonesia siswa MA swasta di Jakarta Selatan (Y)

Hasil penelitian di atas menyimpulkan bahwa kemampuan berpikir kreatif berinteraksi social secara bersama-sama telah memberikan pengaruh positif terhadap peningkatan keterampilan menulis cerita pendek bahasa Indonesia siswa MA Swasta di Jakarta Selatan. Hal ini mengandung arti bahwa kemampuan berpikir kreatif dan berinteraksi sosial telah memberikan pengaruh yang signifikan terhadap peningkatan keterampilan menulis cerita pendek bahasa Indonesia siswa MA Swasta di Jakarta Selatan.

Cerpen adalah bagian dari menulis kreatif. Menulis terbagi atas dua jenis yaitu menulis akademis dan menulis kreatif. Menulis akademis berkaitan dengan suatu hal yang konkret, nyata atau sesuai fakta, sedangkan menulis kreatif berkaitan dengan dunia tidak nyata atau rekaan dan berisi imajinasi. Menulis akademis bersifat non-fiksi dan disusun berdasarkan kaidah penulisan yang baku, biasanya berbentuk karya ilmiah, seperti makalah, skripsi, atau tesis, sedangkan menulis kreatif bersifat fiksi seperti naskah drama, novel dan cerpen.

\section{Pengaruh kemampuan berpikir kreatif (X1) terhadap keterampilan menulis cerita pendek bahasa Indonesia siswa MA swasta di Jakarta Selatan (Y)}

Hasil penelitian di atas menyimpulkan bahwa kemampuan berpikir kreatif telah memberikan pengaruh positif terhadap peningkatan keterampilan menulis cerita pendek bahasa Indonesia siswa MA Swasta di Jakarta Selatan. Hal ini mengandung arti bahwa kemampuan berpikir kreatif, siswa memberikan pengaruh yang cukup signifikan terhadap peningkatan keterampilan menulis cerita pendek bahasa Indonesia siswa MA Swasta di Jakarta Selatan.

Berpikir kreatif sebagai kemampuan umum untuk menciptakan sesuatu yang baru, sebagai kemampuan untuk memberikan gagasan-gagasan baru yang dapat diterapkan dalam pemecahan masalah, atau sebagai kemampuan untuk melihat hubungan-hubungan baru antara unsure-unsur yang sudah ada sebelumnya (Munandar, 1999: 25). Berpikir kreatif merupakan ungkapan (ekspresi) dari keunikan individu dalam interaksi dengan lingkungannya. Ungkapan kreatif inilah yang mencerminkan orisinalitas dari individu tersebut. Dari ungkapan pribadi yang unik dapat diharapkan timbulnya ide-ide baru dan produk-produk yang inovatif dan adanya ciri-ciri seperti: mampu mengarahkan diri pada objek tertentu, mampu memperinci suatu gagasan, mampu menganalisis ide-ide dan kualitas karya pribadi, mampu menciptakan suatu gagasan baru dalam pemecahan masalah (Munandar, 1999: 45) 


\section{Pengaruh Berinteraksi sosial (X2) terhadap Keterampilan menulis cerita pendek bahasa Indonesia siswa MA Swasta di Jakarta Selatan (Y)}

Dari hasil penelitian dan teori yang ada dapat disimpulkan bahwa berinteraksi sosial telah memberikan pengaruh positif terhadap peningkatan keterampilan menulis cerita pendek bahasa Indonesia siswa MA Swasta di Jakarta Selatan. Artinya, berinteraksi sosial yang tinggi telah memberikan pengaruh yang signifikan terhadap peningkatan keterampilan menulis cerita pendek bahasa Indonesia siswa MA Swasta di Jakarta Selatan.

Manusia sebagai makhluk sosial tidak dapat hidup sendirian tanpa kehadiran orang lain. Manusia membutuhkan makanan, udara, persahabatan, ilmu pengetahuan, persekutuan, dan kesusilaan untuk mencukupi kebutuhan, melangsungkan, serta mengembangkan hidupnya. Dengan demikian, manusia perlu berinteraksi dengan sesamanya dan dunia luar agar dapat melangsungkan serta mengembangkan hidupnya.

Bentuk umum proses sosial adalah interaksi sosial (yang juga dapat dinamakan proses sosial) karena interaksi sosial merupakan syarat utama terjadinya aktivitas-aktivitas sosial. Interaksi sosial merupakan hubungan-hubungan sosial yang dinamis yang menyangkut hubungan antara orang perorangan dengan kelompok manusia. (Sukanto, 2015:55).

\section{SIMPULAN}

Berdasarkan hasil dan pembahasan, dapat disimpulkan bahwa terdapat pengaruh yang signifikan kemampuan berpikir kreatif dan berinteraksi sosial secara bersama-sama terhadap keterampilan menulis cerita pendek bahasa Indonesia siswa MA Swasta di Jakarta Selatan. Hal ini dibuktikan dengan perolehan nilai Sig. 0,000 $<0,05$ dan $F_{h}=11,023.2$ ). Terdapat pengaruh yang signifikan kemampuan berpikir kreatif terhadap keterampilan menulis cerita pendek bahasa Indonesia siswa MA Swasta di Jakarta Selatan. Hal ini dibuktikan dengan perolehan nilai Sig. 0,006 < 0,05 dan $t_{h}=2,831.3$ ). Terdapat pengaruh yang signifikan berinteraksi sosial terhadap keterampilan menulis cerita pendek bahasa Indonesia siswa MA Swasta di Jakarta Selatan. Hal ini dibuktikan dengan perolehan nilai Sig. 0,038 < 0,05 dan $\mathrm{t}_{\mathrm{h}}=2,127$.

\section{DAFTAR PUSTAKA}

Arikunto, S. (2006). prosedur penelitian suatu pendekatan praktik. Bandung: PT Rineka Cipta.

Chaer, A., \& Agustina, L. (2004). Sosiolinguistik: Perkenalan awal. Jakarta:

$$
\text { Rineka Cipta }
$$

Dalman, (2014). Keterampilan menulis. Jakata: Rajawali Press.

Munandar, U. (2012). Pengembangan kreativitas anak berbakat. Jakarta: PT Rineka Cipta. 
Diskursus: Jurnal Pendidikan Bahasa Indonesia

Vol. 2, No. 3, Desember 2019, pp. 259-266

p-ISSN: 2615-4935

e-ISSN: 2615-4943

Ridwan, S. (2011). Metodologi pembelajaran bahasa: Aplikasi dalam pengajaran morfologi-sintaksis. Yogyakarta: Kepel Press.

Soekanto, S (2015). Sosiologi Suatu Pengantar. Jakarta: PT Raja Grafindo Persada. 